\title{
BMJ Global Health Time to apply a social determinants of health lens to addressing sickle cell disorders in sub-Saharan Africa
}

\author{
Maria Berghs, ${ }^{1}$ Bola Ola, ${ }^{2}$ Anna Cronin De Chavez, ${ }^{3}$ Bassey Ebenso (D) ${ }^{3}$
}

To cite: Berghs M, Ola B, Cronin De Chavez A, et al. Time to apply a social determinants of health lens to addressing sickle cell disorders in sub-Saharan Africa. BMJ Global Health 2020;5:e002601. doi:10.1136/ bmjgh-2020-002601

Handling editor Seye Abimbola

- Additional material is published online only. To view please visit the journal online (http://dx.doi.org/10.1136/ bmjgh-2020-002601).

Received 7 April 2020 Revised 5 July 2020 Accepted 7 July 2020
Check for updates

(C) Author(s) (or their employer(s)) 2020. Re-use permitted under CC BY-NC. No commercial re-use. See rights and permissions. Published by BMJ.

${ }^{1}$ Unit for the Social Study of Thalassaemia and Sickle Cell, School of Allied Health Sciences, De Montfort University,

Leicester, UK

${ }^{2}$ Department of Psychiatry, Faculty of Clinical Sciences, Lagos State University, Lagos, Nigeria

${ }^{3}$ Institute of Health Sciences, School of Medicine, University of Leeds, Leeds, UK

Correspondence to

Bassey Ebenso;

b.e.ebenso@leeds.ac.uk

\section{INTRODUCTION}

Why do sickle cell disorders (SCDs) remain a low priority on the global child health agenda when a child dies from the condition every three seconds globally? Why are more resources not invested to save lives and ensure holistic care of people with SCDs? Why is policy focus shifting towards development of genomic cures instead of assuring better healthcare for people across the life-course? The disconnect between policy and practice raises further questions. What is the point of a cure if you live in poverty, do not have basics of healthcare and are susceptible to dying from a myriad of other diseases or during a pandemic? For many people, the major complications of inherited genetic conditions like SCDs include intractable pain, organ failure and death, that are often triggered by environmental factors such as malnutrition, dehydration, changes in temperature and stress, all of which are closely tied to socioeconomic factors.

\section{RESEARCH AND PRACTICE IN SILOS}

The preceding global and local inequities have been frustrating, working in our narrow disciplines of health systems, mental health, housing, gender and employment linked to SCD interventions as people with SCDs themselves are advocating for a holistic social justice perspective to SCDs. Similar to public health models that view disease through a medical lens, working in our silos has promoted a compartmentalisation of upstream inequalities and sociopolitical decisions that affect people's health. Moreover, as the COVID-19 pandemic in high-income countries illustrates, ${ }^{12}$ although healthcare access is a critical human right, societal inequality affects which populations become more affected. A more holistic public health policy approach which is grounded in social justice is now
Summary box

Sickle cell disorders are a complex multisystem inherited genetic blood disorders that affect millions of people worldwide and complications of the disorders can include anaemia, pain episodes and organ damage.

- Medical advances, early detection, intervention in infancy and specialised care across the life-course are transforming these genetic blood disorders into chronic conditions, with longer life expectancies and better quality of life, yet public health debates continue to view sickle cell disorders as purely biomedical problems that need to be prevented.

- We argue that adopting a social determinants of health approach to sickle cell disorders can help to move the policy focus from viewing sickle cell disorders as burdens to be prevented, to a more holistic perspective that would ensure better health and well-being across the life-course.

- The social determinants of health promotes a socially just and ethical framing of health and well-being in all policies, that are fundamental to achieving the United Nations Sustainable Development Goals (SDGs), including SDG 10-of reducing health inequalities within and between countries.

urgently demanded. We therefore argue that adopting a 'social determinants of health' (SDH) approach will invigorate public health responses to addressing local and global health inequalities. We start by defining SDH before providing some background to why SCDs are neglected on the global health agenda. Then, we turn to practical policy implications of such an approach and the design of needed interventions for health.

\section{SOCIAL DETERMINANTS OF HEALTH}

SDH refer to the conditions, in the context and places, in which individuals are born, grow, live (including play, learn and work) and age ${ }^{34}$ and SDH are in turn affected by social, political and economic structures, that 
for example, affect healthcare systems. Context here, includes cultural and societal values placed on health, and the extent to which health is regarded as a social concern as well as a human right. By addressing these conditions and structures, we can progress someway to combating inequalities and ensuring equity for people with SCDs. ${ }^{5}$ Analysing the conditions in which people live across the life-course (from birth through to old age rather than cross-sectionally) offers a holistic interpretation of health and well-being at all ages. The SDH also intersects with more than just the third United Nations (UN) Sustainable Development Goal (SDG 3) on health and well-being in society but incorporates all 17 goals. Likewise, SDH are connected to the WHO's One Health agenda to ensure universal healthcare for all people, as well as debates about universal basic income, assuring citizens of a country, a basic income or living stipend. The above issues are important to understanding SCDs.

\section{SCDS AND THE GLOBAL CHILD HEALTH AGENDA}

SCDs are complex multisystem inherited genetic blood disorders that affect millions of people worldwide. SCD includes the most common subtype in sub-Saharan Africa, caused by the homozygous mutation in the betaglobin gene (HBB) that results in the production of an abnormal form of beta-globin called beta-S-globin ( $\mathrm{Hb}$ SS, often called sickle cell disease) $;^{6}$ a separate mutation in HBB that results in production of another abnormal form of beta globin called beta-C-globin ( $\mathrm{Hb} \mathrm{SC}$ ) viewed as milder form of SCD and a rare subtype in sub-Saharan Africa $\mathrm{HbS} /$ beta0thalassaemia. ${ }^{7}$ Despite being declared a major global public health priority by the UN General Assembly, ${ }^{7} \mathrm{SCD}$ is yet to attain prominence on the global child health agenda. Approximately, 300000 babies with sickle cell disease are born globally each year ${ }^{8}$ and $70 \%$ of these births occur in sub-Saharan Africa. Additionally, there are around 150000 child deaths per year due to sickle cell disease, a figure higher than child deaths from HIV/AIDS related causes. ${ }^{9}$ The WHO estimates that around 2\% of births in sub-Saharan Africa are now of SCDs and that mortality particularly affects infants, adolescents and pregnant women with the condition. ${ }^{10}$ In West African countries, like Nigeria, due to improvements in child and maternal mortality rates, as well as an estimated one in four people being carriers of the sickle mutation, ${ }^{11}$ the population of people with SCD is expected to grow. Similarly, more children with SCD are expected to be born globally in Latin-America, Asia, Europe and the Middle East but public health policy has been slow to prepare for the increase in SCD. ${ }^{12}$

\section{CHRONIC CONDITIONS?}

Fortunately, medical advances, early detection and interventions in infancy, as well as specialised multidisciplinary management across the life-course in high income countries, is progressively transforming SCDs into chronic conditions with longer life expectancy and higher quality of life. ${ }^{1314}$ Despite this transformation, contemporary public health discourses still view SCDs as biomedical 'burdens' to be prevented. Correlated to these discourses, we argue that health policies espoused by states typically revolve around four themes: ${ }^{15}$ (1) understanding prevalence; (2) saving lives through screening services; (3) ensuring informed decision-making through access to education and reproductive options and (4) timely healthcare and treatment from healthcare providers. Notwithstanding the potential of such policies to catalyse improved health outcomes for communicable and noncommunicable conditions, these policies have typically been neglected in many African countries, thus forcing individuals to assume the responsibility for some of the strategies with untold psychosocial impacts on them.

The prevailing context of political neglect of policies, limited health systems infrastructure and the narrow biomedical interpretation of SCDs as burdens to be prevented have stimulated global investments in genomic cures for SCD in Africa, for example by the Bill and Melinda Gates Foundation. ${ }^{16}$ While assurances have been made that people in low-income countries will access novel genomic cures, nonetheless, medical cures, on their own, do not address everyday concerns of persons with SCD, especially in the context of ongoing coronavirus pandemic, that include access to psychosocial care, basic medicines to manage severe pain, housing, education, employment and ensuring their and their families' general health and well-being. Furthermore, whereas the availability of the disease modifying drug, Hydroxyurea, is welcome news, unfortunately, the annual cost of taking Hydroxyurea for SCD (US\$300) makes it very expensive for most people in sub-Saharan Africa. Even access to routine treatments like blood transfusions or pain medications are financially prohibitive for patients in many African countries where payment is expected for care. How can we change this?

\section{THE IMPERATIVE OF THE SOCIAL DETERMINANTS OF SCDS}

To ensure a socially just and ethical framing of SCDs, adopting an $\mathrm{SDH}^{17}$ perspective is imperative to understanding the intersection of SCD with conditions of poverty, infectious diseases and environmental triggers that act as risk factors. The SDH views health and wellbeing in all policies, as central to achieving the 2030 UN SDGs. In the figure below, we have outlined how adopting an SDH lens would mean viewing health conditions not as SDH lens would mean viewing health conditions not as 'burdens that need control' but in terms of social justice in total policy environment for sustainable and long-term health for all. ${ }^{18}$ This is especially important in low-income countries where interventions for people with SCDs should be combined with broader investments in the health of the general population. The figure builds on George Engel's biopsychosocial model which argued that understanding the determinants of a person's disease condition required a consideration of 


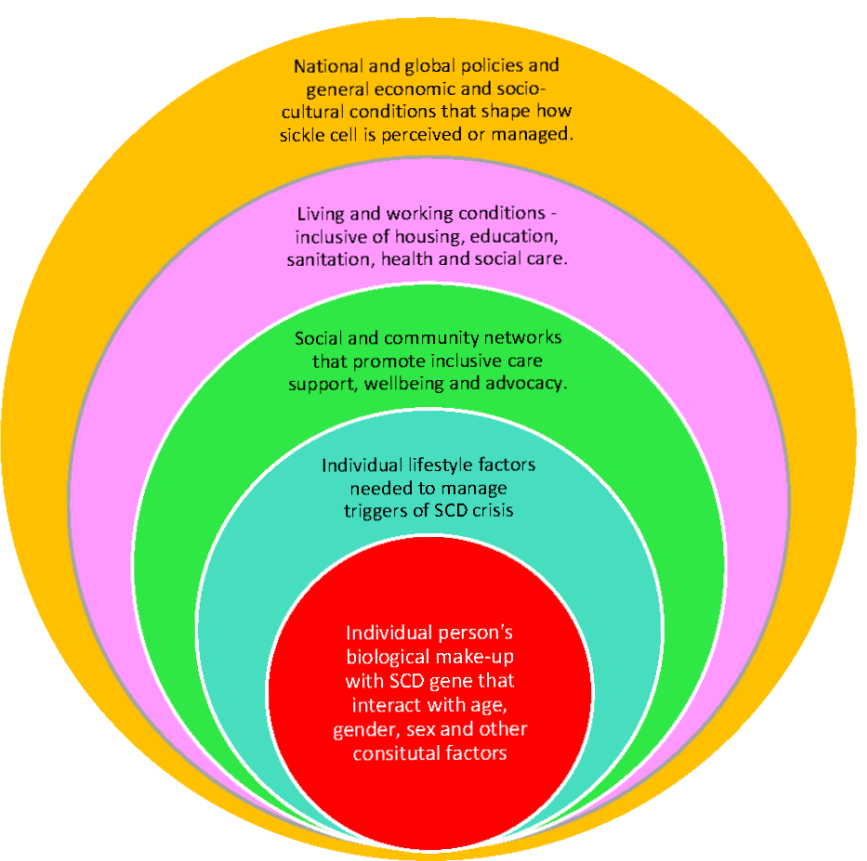

Figure 1 Social determinants of sickle cell disorders: the sickle cell, individual, community knowledge and environment (SICKLE) model.

the biological causes of disease and the psychological and social factors. ${ }^{19}$ To extend Engel's work, Dahlgren and Whitehead ${ }^{20}$ argued that policies and strategies for tackling social inequities in health should focus on key determinants of health that lie outside the health system, including a range of economic growth strategies, inequities in incomes, poverty, unemployment and education.

Adapted from Dahlgren and Whitehead's rainbow model of the SDH, our figure 1 (hereafter called the SICKLE model) depicts a range of factors that can help to move the focus from purely biomedical care of SCD to adopting person-centred approach and help increase the understanding of separate but interlinked factors between the biomedical approach and the wider determinants of health. The figure uses concentric circles (representing individual, community, organisational and wider social contexts) to account for epigenetic, psychosocial and environmental factors that influence SCDs outcomes. These include individual lifestyle factors that trigger SCD crisis; community networks and advocacy activities to support the health and well-being of patients; and broader social policies and socioeconomic and cultural factors. ${ }^{21}{ }^{22}$ The simplicity of this figure can increase its utility in teaching and training practices, to promote the adoption of holistic policies and interventions that are not just medical in nature.

To illuminate the roles of factors depicted in the SICKLE model on the health of persons with SCDs, we have provided a pen portrait (see online supplementary file), structured by sections to map unto various factors highlighted in the SICKLE model (individual factors, lifestyle factors, social and community factors)
Next, we use the context of Nigeria to illustrate the application of the SDH approach to SCDs.

\section{APPLICATION TO PRACTICE}

Nigeria has one of the largest populations of people with SCDs but also has extreme economic inequalities. The lack of SCD-related policies and the adoption of a biomedical approach to SCDs, mean the institutions of society (including family, universities and churches) directively expect those with the sickle cell trait (those who carry a gene) to understand their status and its implications. In such contexts, a couple that both have sickle cell trait (with a one in four chance of having a child with sickle cell disease in each pregnancy) are counselled to avoid marriage and sexual relations. The high fatality rate of sickle cell disease (ie, Hb SS disease) in sub-Saharan Africa, often intersects with deprivation and political and economic instability to create fatalistic assumptions that children cannot live beyond 5 years old or will not reach the age of 18 .

Such values and norms can increase stigmatisation linked to carrier status and giving birth to a child with SCD. Expecting individuals to take responsibility for SCDs also makes assumptions about agency and family life by implying that all women have choice and say over their reproductive futures, further shaming those who do not take control of reproduction in ways that match societal expectation(s). Moreover, divestment of public health policies also unethically and inadvertently fosters stigma, sexism and (dis)ableism affecting people with SCDs and those with carrier status. In such contexts, we argue instead that policy and interventions development for SCDs could be conceptualised with ensuring equity and reducing inequalities as their main aim as shown in table 1 . This conceptualisation will benefit both people with SCD and the general population too.

Table 1 depicts how interventions can manifest depending on the perspectives (biomedical approaches vs SDH) and policies that underlie their development.

\section{CONCLUSION}

The comparison of key features of interventions in the table suggests that a purely biomedical/biopsychosocial framing of SCD as burden sets in motion a series of public health policies that inadvertently ignore a duty of care and right to health. A biomedical approach also fosters unethical practices that are inconsistent with contemporary understandings about SCD being clinically, as much as socially and environmentally determined. The ongoing COVID-19 pandemic shows the importance of thinking about health inequalities in broader social justice terms, to understand why some people are more affected but also to ensure provision of high-quality care and mutual aid to people with disabilities and SCD. The postpandemic situation cannot mean political business as usual as the improved survival and quality of life of millions of people with SCD in sub-Saharan Africa depends on holistic 
Table 1 Showing features of key interventions by the perspectives that underpin their design

\begin{tabular}{ll}
\hline Interventions & Biomedical and biopsychosocial approaches \\
\hline Estimating prevalence & $\begin{array}{l}\text { Magnitude of SCDs is seen as a burden, that } \\
\text { potentially stigmatises people with SCDs and carrier } \\
\text { status. }\end{array}$
\end{tabular}

Screening services

Identify children with SCDs to ensure care. This can cause stigmatisation of women carrying children with SCDs and people with SCDs.

$\begin{array}{ll}\text { Medical care } & \text { SCDs often seen as a specialised issue in health } \\ \text { services with need for particular training. Under- } \\ \text { invested and neglected. Payment expected for } \\ \text { treatment. Research focuses on development of } \\ \text { cures and new therapies neglected for years. } \\ \text { Mental health } \\ \begin{array}{l}\text { Identify mental health issues such as depression } \\ \text { and stress as triggers for SCD crisis. The condition } \\ \text { is viewed as stigmatised. }\end{array}\end{array}$

Cifestyle $\quad \begin{aligned} & \text { Care and nutrition viewed as family and individual } \\ & \text { management usually targeted to mothers as part of } \\ & \text { early intervention programmes. }\end{aligned}$

School

$\begin{array}{ll}\text { Employment } & \text { People with SCDs are unable to work due to } \\ \text { invisible disabilities or require special provisions to } \\ \text { work. }\end{array}$

Housing and sanitation Housing and sanitation excluded from these approaches.

Environment
Environmental conditions viewed as 'trigger' for
disease, warnings about extremes in temperature
but no policies to support improvements in
environmental conditions.

\section{Social determinants of health}

Prevalence is seen as part of holistic policies that combine life-course approach and universal access to healthcare for people with SCDs and general population.

Screen to ensure timely treatment to save lives of those born with SCDs and also ensure family planning, reproductive choices and maternal health policy exists in society.

SCD is considered specialised but it incorporates duty of care and is linked to other parts of healthcare and investments made in therapies. Universal health coverage is implemented alongside investments in cures. Recognition of pluralistic health belief systems and importance of patient support groups.

Health and social care focus on strengthening friendships, relationships and community connections that support persons with SCDs to cope better and understand psychological stressors.

Care and nutrition as part of a country's policies for general population taught in schools, universities and public communication programmes. The contribution of the extended family and community in care of those with SCDs is recognised.

SCDs integrated in all aspects of education and inclusive disability policies in schools and higher education institutions.

Work is made accessible for those with invisible disabilities with reasonable adjustments, welfare (or a basic universal income) and pension plans for people with chronic conditions exist in society.

Housing and sanitation should be safe and accessible. Hygiene taught in schools.

Environmental policies focused on housing conditions, access to heating and/or air conditioning to support a stable body temperature. Climate change and reduction of pollution. Disability and chronic conditions included in pandemic preparedness and planning throughout.

SCD, sickle cell disorders.

policies and strategies that are underpinned by an $\mathrm{SDH}$ approach to SCD, rather than on screening programmes or clinical treatments and cures alone. While the interventions listed in table 1 are not meant to be exhaustive, applying an SDH lens to implement them will accelerate the achievement of several UN SDGs. Notable for people with SCD are as follows: goal 1 of ending poverty, goal 2 of ending hunger and improving nutrition, goal 3 of ensuring healthy lives and improving well-being, goal 4 of ensuring inclusive education and lifelong learning, goal
5 of achieving gender equality and goal 8 of promoting full and productive employment for all.

Twitter Maria Berghs @MariaBerghs and Bassey Ebenso @B_Ebenso

Contributors $\mathrm{MB}, \mathrm{BO}, \mathrm{ACDC}$ and $\mathrm{BE}$ jointly conceived the commentary and contributed equally to its writing. All authors read and approved the final version of the manuscript.

Funding The authors have not declared a specific grant for this research from any funding agency in the public, commercial or not-for-profit sectors.

Competing interests None declared.

Patient consent for publication Not required. 
Provenance and peer review Not commissioned; externally peer reviewed.

Data availability statement No data are available to share.

Open access This is an open access article distributed in accordance with the Creative Commons Attribution Non Commercial (CC BY-NC 4.0) license, which permits others to distribute, remix, adapt, build upon this work non-commercially, and license their derivative works on different terms, provided the original work is properly cited, appropriate credit is given, any changes made indicated, and the use is non-commercial. See: http://creativecommons.org/licenses/by-nc/4.0/.

ORCID iD

Bassey Ebenso http://orcid.org/0000-0003-4147-0968

\section{REFERENCES}

1 Pareek M, Bangash MN, Pareek N, et al. Ethnicity and COVID-19: an urgent public health research priority. Lancet 2020;395:1421-2.

2 Dorn Avan, Cooney RE, Sabin ML. COVID-19 exacerbating inequalities in the US. Lancet 2020;395:1243-4.

$3 \mathrm{WHO}$. Closing the gap in a generation: health equity through action on the social determinants of health : final report of the Commission on Social Determinants of Health. Geneva: World Health Organization, 2008.

4 WHO. Commission on social determinants of health: a conceptual framework for action on the social determinants of Health-Discussion paper for the Commission on social determinants of health. draft. Geneva: World Health Organization, 2007.

5 Raphael JL. Addressing social determinants of health in sickle cell disease: the role of Medicaid policy. Pediatr Blood Cancer 2020;67:e28202.

6 Modell B, Darlison M. Global epidemiology of haemoglobin disorders and derived service indicators. Bull World Health Organ 2008;86:480-7.

7 Grosse SD, Odame I, Atrash HK, et al. Sickle cell disease in Africa: a neglected cause of early childhood mortality. Am J Prev Med 2011;41:S398-405.

8 Piel FB, Hay SI, Gupta S, et al. Global burden of sickle cell anaemia in children under five, 2010-2050: modelling based on demographics, excess mortality, and interventions. PLoS Med 2013;10:e1001484

9 UNICEF. Hiv/Aids: global and regional trends, 2019. Available: https://data.unicef.org/topic/hivaids/global-regional-trends/ [Accessed 2nd February 2020].

10 WHO. Sickle-Cell disease: a strategy for the who African region Malabo, Equatorial Guinea: World Health Organization, 2011.

11 Burnham-Marusich AR, Ezeanolue CO, Obiefune MC, et al. Prevalence of sickle cell trait and reliability of self-reported status among expectant parents in Nigeria: implications for targeted newborn screening. Public Health Genomics 2016;19:298-306.

12 Tluway F, Makani J. Sickle cell disease in Africa: an overview of the integrated approach to health, research, education and advocacy in Tanzania, 2004-2016 2017;177:919-29.

13 Chakravorty SAK, Dziwinski S, Kaya B, et al. (2019) optimising the transition from paediatric to adult care model for people with sickle cell disease - a UK multidisciplinary consensus statement. Health Sciences Journal 2019;13:1-10.

14 Shet AS, Thein SL. A growing population of older adults with sickle cell disease. Clin Geriatr Med 2019;35:349-67.

15 Dyson SM. Sickle cell and the social sciences: health, racism and disablement. Taylor \& Francis, 2019.

16 Simpson S. Sickle cell disease: a new era. Lancet Haemato 2019;6:e393-4.

$17 \mathrm{CSDH}$. Closing the gap in a generation: health equity through action on the social determinants of health. final report of the Commission on social determinants of health. Geneva, World Health Organization: World Health Organization, 2008.

18 Berghs M, Atkin K, Hatton C, et al. Rights to social determinants of flourishing? a paradigm for disability and public health research and policy. BMC Public Health 2019;19:997.

19 Engel GL. The need for a new medical model: a challenge for biomedicine. Science 1977;196:129-36.

$20 \mathrm{Gr}$ D, Whitehead M. WHO. Levelling up (part 2) : a discussion paper on European strategies for tackling social inequities in health / by Göran Dahlgren and Margaret WHitehead. Copenhagen: WHO Regional Office for Europe, 2006.

21 Piel FB, Steinberg MH, Rees DC. Sickle cell disease. N Engl J Med 2017;376:1561-73.

22 Ola BA, Yates SJ, Dyson SM. Living with sickle cell disease and depression in Lagos, Nigeria: a mixed methods study. Soc Sci Med 2016;161:27-36. 